\title{
Pengaruh $G C G$ Dan Karakteristik Perusahaan Terhadap Kecenderungan Mengungkapkan Kebijakan Anti Korupsi
}

\author{
Iriene Dyah Ayu Tirtasari \\ Universitas Katolik Soegijapranata \\ irienedyahayu@gmail.com \\ Octavianus Digdo Hartomo \\ Universitas Katolik Soegijapranata \\ digdo@unika.ac.id
}

\begin{abstract}
Corruption is still a serious problem in Indonesia. Based on Transparency International website, in 2017 was ranked 96 of corruption out of 180 countries in the world. This low score indicates that the level of corruption in Indonesia is still high. The objective of the study is to test and analyze the influences of good corporate governance $(G C G)$ and firm characteristic towards the tendency to disclose anti-corruption policies in the company. Corporate Governance is reflected by four variables : board independence, audit committee competence, institutional ownership, and gender diversity on BoC. While company characteristics consist of company size and industry risk. Samples are collected from listed companies in BEI (Bursa Efek Indonesia) from 2013 to 2017. Sampling method used in this study was purposive sampling. A total sample of 1619 companies were used in analysis. This study used logistic regression analysis to examine independent variables on dependen variable. Results from this study showed that independent board member, and company size were significant and have a positive affect on anti corruption disclosure. Audit committee competencies and institutional ownership not significant to anti corruption disclosure. While industry risk was significant and negative affectt on anti corruption disclosure.
\end{abstract}

Keyword : anti corruption disclosure, transparency, good corporate governance (GCG), firm characteristic

\begin{abstract}
Abstrak
Korupsi masih menjadi permasalahan serius di Indonesia. Berdasarkan website Transparency International, pada tahun 2017 Indonesia menduduki peringkat 96 dari 180 negara di dunia. Skor yang masih rendah ini mengindikasikan bahwa masih tingginya tingkat korupsi di Indonesia. Tujuan dari penelitian ini adalah untuk menguji dan menganalisis pengaruh dari tata kelola perusahaan dan karakteristik perusahaan terhadap kecenderungan mengungkapkan kebijakan anti korupsi di perusahaan. Tata kelola perusahaan dicerminkan oleh empat variabel yakni independensi dewan komisaris, kompetensi komite audit, kepemilikan institusional dan keberagaman gender dalam anggota komisaris. Sedangkan karakteristik perusahaan dicerminkan oleh ukuran perusahaan dan risiko industri. Sampel dalam penelitian ini adalah perusahaan yang terdaftar di Bursa Efek Indonesia (BEI) pada tahun 2013 hingga 2017. Pemilihan sampel pada penelitian ini menggunakan metode purposive sampling dengan total perusahaan sebanyak 1619 perusahaan. Penelitian ini menggunakan analisis regresi logistik untuk menguji pengaruh variabel independen terhadap variabel dependen. Hasil dari penelitian ini menunjukkan bahwa independensi dewan komisaris, dan ukuran perusahaan berpengaruh positif terhadap kecenderungan mengungkapkan kebijakan anti korupsi di perusahaan. Variabel kompetensi komite audit dan kepemilikan institusional tidak berpengaruh terhadap kecenderungan mengungkapkan kebijakan anti korupsi di perusahaan. Sedangkan risiko
\end{abstract}


industri berpengaruh negatif terhadap kecenderungan mengungkapkan kebijakan anti korupsi di perusahaan.

\section{Kata Kunci : pengungkapan kebijakan anti korupsi, transparansi, Good Corporate Governance, karakteristik perusahaan}

\section{PENDAHULUAN}

Pada masa sekarang ini dunia bisnis di Indonesia bukan hanya berorientasi pada kinerja keuangannya saja tetapi juga perlu menunjukkan upaya untuk meningkatkan kredibilitas serta komitmen terhadap praktik bisnis yang bersih dan beretika. Namun pada kenyataannya perkembangan bisnis yang pesat sering tidak di imbangi dengan pengendalian internal yang baik. Maraknya kasus korupsi yang menjerat perusahaan-perusahaan di Indonesia, menjadi bukti lemahnya fungsi tata kelola yang ada di perusahaan.

Korupsi sampai saat ini masih menjadi permasalahan serius di Indonesia. Berdasarkan informasi yang diperoleh dari websiteTransparency International, pada tahun 2017 Indonesia memperoleh skor Indeks Persepsi Korupsi sebesar 37 dan menduduki peringkat 96 dari 180 negara pada tahun 2017. Peringkat yang terbilang rendah ini, mengindikasikan bahwa masih tingginya tingkat korupsi di Indonesia. Berdasarkan data dari website https://acch.kpk.go.idmenunjukkan bahwa korupsi paling banyak menjerat anggota DPR dan DPRD serta sektor swasta. Korupsi menjadi musuh bersama karena memiliki dampak kerugian baik keuangan maupun non keuangan dan dapat mengancam kelangsungan hidup perusahaan. Maka dari itu, untuk meminimalisir praktik bisnis yang tidak beretika diperlukan sebuah mekanisme yang disebut Good Corporate Governance.

Good Corporate Governance (GCG) sebagai salah satu bentuk pengendalian internal sangat perlu dilakukan untuk meminimalisir segala bentuk perilaku menyimpang yang ada di perusahaan, termasuk tindakan korupsi. Menurut Widyatama(2014) GCG merupakan sebuah konsep yang harus diimplementasikan oleh perusahaan guna meminimalisir bentuk ketimpangan antara manajer dan investor. GCG mampu digunakan sebagai alat untuk mencegah korupsi karena melalui penerapan asas responsibilitas dan transparansi menjadi kunci utama terciptanya keterbukaan informasi di perusahaan. Salah satu informasi yang disoroti adalah mengenai pengungkapan kebijakan anti korupsi di perusahaan.

Pengungkapan kebijakan anti korupsi merupakan salah satu bentuk pengungkapan sukarela yang merepresentasikan komitmen perusahaan untuk memerangi korupsi. Pengungkapan kebijakan anti korupsi sangat diperlukan agar para pemangku kepentingan mengetahui upaya perusahaan dalam menciptakan bisnis yang beretika dan upaya untuk menjaga kepentingan seluruh stakeholder nya. Di dalam program anti korupsi memaparkan kebijakan diantaranya mengenai larangan suap, anti gratifikasi, kerjasama dengan KPK untuk melawan gratifikasi, serta. membentuk dan menerapkan sistem whistleblowing.

Penelitian ini menganalisis pengaruh Good Corporate Governance (GCG) dan karakteristik perusahaan terhadap kecenderungan mengungkapkan kebijakan anti korupsi di perusahaan Indonesia.Penelitian ini merupakan pengembangan dari penelitian De $\mathrm{Melo}(2015)$ dengan tambahan variabel kompetensi komite audit audit (Allegrini dan Greco, 2013) serta Bedard dan Gendron (2010) dalam Musallam(2018); variabel kepemilikan institusional (Rouf dan Harun, 2011); serta variabel ukuran perusahaan dan risiko industri (Healy dan Serafeim, 2011).

Penelitian ini bertujuan untuk menguji kembali faktor-faktor yang mempengaruhi kecenderungan perusahaan dalam mengungkapkan kebijakan anti korupsi dengan konteks perusahaan yang ada di Indonesia dan terdaftar di Bursa Efek Indonesia (BEI). 


\section{LANDASAN TEORI DAN PERUMUSAN HIPOTESIS}

\section{Teori Agensi}

Suatu pandangan yang dibangun melalui teori agensi adalah anggapan mengenai sikap individualistis pada setiap orang yang akan memicu perbedaan kepentingan antara principal dan agent(Yulio, 2016). Teori Keagenan menyatakan bahwa mekanisme pengawasan yang diterapkan perusahaan dalam bentuk GCG, akan mampu mengurangi konflik kepentingan dan asimetri informasi untuk meredam perbedaan kepentingan dari berbagai pihak dalam perusahaan.Karena dengan adanya implementasi GCG di perusahaan, pengawasan menjadi lebih ketat dan independensi dalam pengambilan keputusan dapat terjaga.

\section{Teori Legitimasi}

Teori ini berdasar pada pandangan bahwa adanya kontrak sosial antara perusahaan dengan lingkungan sekitarnya yang menuntut perusahaan melaporkan kegiatannya secara sukarela. Legitimasi dianggap menjadi hal krusial bagi perusahaan karena legitimasi dari masyarakat merupakan faktor yang menentukan perkembangan dan kelangsungan hidup perusahaan (Karim, 2016). Untuk mendapat legitimasi tersebut, maka perusahaan harus mengkomunikasikan aktivitas lingkungan dengan melakukan pengungkapan sosial dan lingkungan (Robert et al, 2011).

\section{Korupsi}

Menurut Undang-Undang No.31 Tahun 1999 tentang Pemberantasan Tindak Pidana Korupsi, yang termasuk dalam tindak pidana korupsi adalah setiap orang yang dikategorikan melawan hukum, melakukan kegiatan memperkaya diri sendiri, menguntungkan diri sendiri atau orang lain atau suatu korporasi, menyalahgunakan kewenangan maupun kesempatan atau sarana yang ada padanya karena jabatan atau kedudukan yang dapat merugikan keuangan atau perekonomian Negara. Berdasarkan UU No.31/1999 Jo.UU No.20/2001, korupsi dirumuskan dalam 30 jenis tindak pidana korupsi (tipikor), yang dikelompokkan menjadi tujuh jenis besar, yakni (1) Kerugian Keuangan Negara, (2) Suap Menyuap, (3) Penggelapan dalam Jabatan, (4) Pemerasan, (5) Perbuatan Curang, (6) Konflik Kepentingan dalam Pengadaan, dan (7) Gratifikasi.

\section{Good Corporate Governance (GCG)}

Good Corporate Governance merupakan suatu sistem, dan proses yang dilakukan oleh organ perusahaan seperti Direksi, Dewan Komisaris, dan RUPS dalam rangka memberikan feedback kepada shareholder, namun tetap memperhatikan kepentingan stakeholder lainnya, sesuai dengan peraturan perundangan yang berlaku (Putra, 2016). GCG merupakan suatu gagasan harus diterapkan dalam suatu perusahaan dengan tujuan untuk mengurangi gap antara manajer dan investor (Widyatama, 2014).

Menurut Komite Nasional Kebijakan Governance (2006) terdapat lima asas GCG yakni (1) Transparansi, (2) Akuntabilitas, (3) Responsibilitas, (4) Independensi, serta (5) Kewajaran dan Kesetaraan. Dengan adanya kelima asas ini, utamanya asas transparansi dan responsibilitas perusahaan diharapkan mengungkapkan komitmen perusahaan, salah satunya upaya anti korupsi sebagai sebuah bentuk pertanggungjawaban kepada pemangku kepentingan. Tata kelola perusahaan yang baik tidak hanya mengakibatkan meningkatnya efisiensi, dan menjamin keberlanjutan namun juga berfungsi sebagai alat anti korupsi yang efektif (Sullivan et al, 2013).

Dalam penelitian ini ada empat elemen GCG yang akan dibahas yakni (1) Komisaris Independen, (2) Kompetensi Komite Audit, (3) Struktur Kepemilikan Institusional dan (4) Keberagaman Gender dalam anggota komisaris. 


\section{Komisaris Independen}

Menurut Peraturan OJK No.33/POJK.04.2014 tentang Direksi dan Dewan Komisaris Emiten atau Perusahaan Publik menyatakan bahwa Komisaris Independen adalah anggota Dewan Komisaris yang berasal dari luar emiten, yang tidak memiliki hubungan keuangan, kepengurusan, kepemilikan saham, dan atau keluarga dengan anggota Dewan Komisaris lainnya, Direksi, dan atau Pemegang Saham Pengendali, yang dapat mempengaruhi kemampuannya untuk bertindak independen. Independensi yang dimiliki dewan komisaris diharapkan mampu menghadirkan pengawasan yang lebih efektif dan semakin mendorong perusahaan dalam mengungkapkan kebijakan anti korupsi dalam rangka mempertahankan kelangsungan hidup perusahaan dan bentuk pertanggungjawaban kepada stakeholder.

\section{Kompetensi Komite Audit}

Komite audit adalah sekelompok orang yang dipilih oleh kelompok yang lebih besar untuk mengerjakan pekerjaan tertentu atau untuk melakukan tugas-tugas khusus (Tugiman, 1995). Menurut Komite Nasional Kebijakan Governance (2006), Komite Audit merupakan komite penunjang Dewan Komisaris yang bertugas untuk (1) Memastikan laporan keuangan disajikan sesuai dengan prinsip akuntansi, (2) Memastikan terlaksananya pengendalian internal yang baik, (3) Memastikan terlaksananya audit internal maupun eksternal sesuai standar audit yang berlaku dan (4) Memastikan tindak lanjut temuan hasil audit dilaksanakan oleh manajemen.

Komite audit juga dituntut memiliki kompetensi yang memadai. Hal tersebut selaras dengan isi dari Komite Nasional Kebijakan Governance (2006) yang menyatakan bahwa salah seorang anggota Komite Audit haruslah memiliki latar belakang dan kompetensi di bidang akuntansi dan atau keuangan. Kompetensi di bidang akuntansi dan atau keuangan tentu akan mempermudah tugasnya untuk melakukan pemantauan agar meminimalisir risiko kecurangan dalam perusahaan dalam rangka menciptakan asas transparansi.

\section{Struktur Kepemilikan Institusional}

Menurut Gumilang, dkk (2015) kepemilikan institusional merupakan suatu keadaan dimana struktur kepemilikan saham mayoritas suatu perusahaan dimiliki oleh sebuah lembaga seperti, perusahaan asuransi, bank, perusahaan investasi, koperasi, institusi pemerintah dan kepemilikan institusi lainnya. Investor institusional biasanya memiliki hak yang lebih besar dalam suatu perusahaan karena jumlah saham yang diinvestasikan lebih besar daripada investor lainnya. Kkepemilikan institusional memiliki peranan yang sangat penting dalam meminimalisir konflik keagenan yang terjadi antara manajer dan pemegang saham (Jensen dan Meckling, 1976). Sehingga demikian kepemilikan institusional mempunyai pengaruh terhadap bagaimana komitmen perusahaan terhadap anti korupsi.

\section{Keberagaman Gender}

Menurut Marzuki (2007) gender adalah suatu sifat yang dijadikan dasar untuk mengidentifikasi perbedaan antara laik-laki dan perempuan dilihat dari segi kondisi sosial dan budaya, nilai dan perilaku, mentalitas, emosi, serta faktor-faktor non biologis lainnya. Adapun definisi lain yang diungkapkan oleh Puspitawati (2013) yang menyatakan bahwa gender dapat diartikan sebagai perbedaan peran, fungsi, status, dan tanggung jawab pada laki-laki dan perempuan yang terjadi karena adanya proses sosialisasi yang dialami secara terus menerus atau dari satu generasi ke generasi berikutnya. Dengan demikian dapat dikatakan bahwa gender akan membentuk perilaku seseorang berkaitan dengan bagaimana mereka berpikir dan bertindak. Sehingga hal ini akan mempengaruhi perbedaan pengambilan keputusan dan juga dalam pengaruhnya pada perusahaan dalam melakukan pengungkapan informasi. Pada dasarnya perempuan dianggap lebih memiliki sikap kehati-hatian dan tidak ingin mengambil risiko sehingga keputusan yang diambil dinilai cukup tepat dan rendah risiko. Dengan adanya 
dewan komisaris perempuan dalam jajaran anggota komisaris tentu akan mempengaruhi bagaimana upaya perusahaan untuk mencegah korupsi.

\section{Ukuran Perusahaan}

Ukuran perusahaan merupakan cerminan kegiatan operasional klien dan juga menggambarkan pendapatan yang diperoleh perusahaan dalam periode tertentu (Dawami dan Maradina, 2012). Artinya bahwa jika perusahaan tersebut tergolong perusahaan yang besar, maka pendapatan yang diperoleh akan tinggi.Perusahaan besar tentu akan mendapat perhatian lebih dari para stakeholder dan pemangku kepentingan lainnya karena perusahaan tersebut dianggap telah berhasil menjalankan bisnisnya dan berhasil membangun image serta kepercayaan publik. Menurut UU Republik Indonesia No. 20 tahun 2008, menyebutkan bahwa ada 4 jenis ukuran perusahaan yang dapat dinilai dari jumlah penjualan dan aset yang dimiliki oleh perusahaan yakni (1) Perusahaan ukuran mikro, (2) Perusahaan kecil, (3) Perusahaan ukuran menengah, dan (4) Perusahaan besar.

\section{Risiko Industri}

Berkaitan dengan beragamnya jenis Industri di Indonesia, tentu akan memiliki karakteristik dan risiko yang berbeda pula terhadap praktik korupsi. Risiko tersebut dibedakan menjadi dua, yaitu industri high risk dan industri low risk. Dalam jurnalnya Healy dan Serafeim (2011) menyatakan bahwa industri yang menjual produk dan layanan kepada pelanggan pemerintah dianggap berisiko tinggi. Berdasarkan identifikasi dari Transparency International industri yang berisiko tinggi tersebut termasuk industri minyak dan gas, kehutanan, pertambangan, pertahanan, konstruksi, dan telekomunikasi. Dengan keberadaan suatu perusahaan di industry yang high atau low risk tentu akan mempengaruhi bagaimana komitmen dan pengungkapan informasi mereka terhadap program anti korupsi.

\section{Perumusan Hipotesis \\ Independensi Dewan Komisaris}

Kehadiran Komisaris Independen dalam komposisi Dewan Komisaris akan meminimalkan konflik kepentingan dan juga intervensi dari pihak manapun, sehingga pengambilan keputusan oleh Direksi dilakukan secara objektif. Sebagai pihak yang tidak mempunyai intervensi atau konflik kepentingan di dalam perusahaan, komisaris independen hanya berfokus pada kelangsungan hidup perusahaan dan memastikan perusahaan dikelola dengan baik. Oleh karena itu, komisaris independen akan mendorong pihak manajemen melakukan upaya untuk menciptakan lingkungan bisnis yang bersih dan sehat dengan melakukan pengungkapan informasi yang akan memberi feedback baik bagi perusahaan tersebut.

Dalam tugasnya dewan komisaris juga ikut serta dalam menjaga kepentingan pemegang saham dan pemangku kepentingan lain. Sehingga semakin independen dewan komisaris akan meningkatkan transparansi dalam pelaporan informasi perusahaan. Salah satu upaya pelaporan yang dilakukan adalah dengan mengungkapkan kebijakan anti korupsi di perusahaan sebagai upaya pencegahan dan juga bentuk komitmen perusahaan terhadap shareholder dan pemangku kepentingan lainnya. Oleh karena itu dapat dikatakan bahwa semakin independen dewan komisaris akan mendorong komitmen dan kecenderungan mengungkapkan kebijakan anti korupsi di perusahaan. Penelitian Healy dan Serafeim (2015) yang dikutip dalam de Melo (2015), yang menyimpulkan bahwa proporsi komisaris independen mempunyai hubungan yang positif terhadap pengungkapan anti korupsi. Hal ini juga selaras dengan hasil penelitian Healy Serafeim (2014) yang dikutip dalam Joseph et al., (2016). Dengan demikian, maka hipotesis dalam penelitian ini adalah :

\section{H1 : Semakin tinggi independensi Dewan Komisaris, maka semakin tinggi pula kecenderungan perusahaan mengungkapkan kebijakan anti korupsi}




\section{Kompetensi Komite Audit}

Tugiman (1995) menyatakan bahwa anggota komite audit disamping harus ahli di bidangnya juga dituntut untuk mengetahui dan menguasai bidang akuntansi dan auditing serta mengetahui dan menguasai analisa laporan keuangan. Komite audit yang memiliki kompetensi di bidang akuntansi dan atau keuangan telah dibekali ilmu mengenai fraud dan tentu lebih memahami mengenai berbagai macam bentuk fraud, faktor-faktor yang mendorong terjadinya fraud (fraud triangle), dan juga lebih memahami mengenai tindakan pencegahan atau mekanisme untuk meminimalisir terjadinya fraud. Atau dengan kata lain komite audit yang berkompeten lebih mampu meminimalkan kesalahan pengukuran akuntansi, berkurangnya pengungkapan akuntansi yang tidak tepat dan meminimalkan tindakan ilegal dan tindakan kecurangan manajemen.

Kompetensi akuntansi dan atau keuangan yang dimiliki komite audit diharapkan semakin mendorong transparansi pelaporan keuangan yang merupakan salah satu cerminan perilaku anti korupsi. Dengan demikian semakin kompeten komite audit dibidang akuntansi dan atau keuangan berkorelasi dengan semakin tingginya kecenderungan mengungkapkan kebijakan anti korupsi di perusahaan. Penelitian Bedard dan Gendron (2010) dalam (Musallam, 2018)berpendapat bahwa komite audit yang memiliki kompetensi di bidang keuangan akan memacu pihak manajemen dan audit eksternal meningkatkan kualitas laporan keuangannya, yang tentu akan berdampak pada peningkatan peningkatan pelaporan kebijakan perusahaan mengenai anti korupsi dan mengurangi biaya agensi. Hal ini selaras dengan penelitian yang dilakukan oleh Allegrini dan Greco (2013).Dengan demikian, maka hipotesis dalam penelitian ini adalah :

\section{H2 : Semakin tinggi jumlah Komite Audit yang berkompeten, maka semakin tinggi pula kecenderungan perusahaan mengungkapkan kebijakan anti korupsi.}

\section{Kepemilikan Institusional}

Keberadaan kepemilikan institusional disuatu perusahaan akan mendukung praktik anti korupsi di perusahaan sebab kepemilikan institusional memiliki peranan yang sangat penting dalam meminimalisir konflik keagenan yang terjadi antara manajer dan pemegang saham (Jensen dan Meckling, 1976). Investor institusional umumnya memiliki hak lebih karena saham yang dimiliki di perusahaan lebih banyak dibandingkan dengan investor lain. Kondisi tersebut akan memperketat pengawasan mereka terhadap manajemen dalam rangka mempertahankan kinerja perusahaan yang baik agar berdampak pada keuntungan atau feedback dari kegiatan investasinya. Pemilik saham institusional akan mendorong pihak manajemen untuk mengungkapkan kebijakan anti korupsi di perusahaannya sebagai suatu upaya pencegahan dan bentuk komitmen perusahaan untuk anti korupsi.

Pengungkapan mengenai anti korupsi diperlukan karena korupsi merupakan permasalahan krusial dan apabila terjadi dalam sebuah bisnis tentu akan mempunyai dampak kerugian yang luar biasa bagi investor institusional tersebut. Sehingga dapat dikatakan bahwa semakin tingginya jumlah kepemilikan institusional maka akan semakin memperketat pengawasan dan mendorong pengungkapan kebijakan anti korupsi di perusahaan sebagai wujud asas transparansi serta komitmen perusahaan untuk memerangi korupsi.

Penelitian El-Gazzar (1998) dalam Eng dan Mak(2003)menyatakan bahwa ada korelasi positif antara kepemilikan institusional dengan pengungkapan perusahaan. Hal ini selaras dengan penelitian yang dilakukan Murwaningsari (2009) serta Rouf dan Harun (2011). Dengan demikian, maka hipotesis dalam penelitian ini adalah :

\section{H3 : Semakin tinggi kepemilikan institusional, maka semakin tinggi pula kecenderungan perusahaan untuk mengungkapkan kebijakan anti korupsi.}




\section{Ukuran Perusahaan}

Semakin besar perusahaan tentu semakin besar jaringan relasi dengan berbagai pihak. Selain itu perusahan besar akan lebih mendapat perhatian khusus dari publik atau dengan kata lain lebih menjadi sorotan publik. Maka untuk tetap menjaga nama baik perusahaan dan kepercayaan publik perusahaan besar akan melakukan upaya pembuktian bahwa kegiatan bisnis yang berlandaskan etika kejujuran dan mengungkapkan segala informasi mendukung.

Korupsi menjadi ancaman besar bagi dunia bisnis sebab apabila perusahaan besar melakukan korupsi maka pemberitaannya akan lebih disorot oleh masyarakat dan menimbulkan kerugian baik material maupun non material. Maka sebagai upaya antisipasi dan mempertahankan kelangsungan hidupnya, perusahaan besar akan lebih terdorong mempublikasikan kebijakan anti korupsinya dalam laporan tahunan perusahaan. Sehingga dapat dikatakan bahwa perusahan besar akan lebih terdorong mengungkapkan kebijakan anti korupsinya sebagai salah satu bentuk pertanggungjawaban dan mempertahankan kredibilitasnya. Penelitian Patten(1991) dalam jurnalnya menjelaskan bahwa perusahaan besar cenderung menerima lebih banyak perhatian dari masyarakat umum dan kondisi ini menyebabkan perusahaan berada dibawah tekanan publik yang lebih besar untuk menunjukkan tanggung jawab sosialnya, salah satunya adalah dengan mengungkapkan kebijakan anti korupsi. Hal ini selaras dengan penelitian yang dilakukan oleh Healy dan Serafeim (2011) serta Trotman dan Bradley (1981).

H4 : Semakin besar ukuran perusahaan, maka semakin tinggi pula kecenderungan perusahaan mengungkapkan kebijakan anti korupsi.

\section{Risiko Industri}

Hasil identifikasi Transparency International yang dimuat dalam jurnal Healy dan Serafeim (2011) industri yang termasuk high risk tersebut termasuk minyak dan gas, kehutanan, pertambangan, pertahanan, konstruksi, dan telekomunikasi.Perusahaan yang berada dalam kategori high riskakan lebih terdorong atau mempunyai upaya yang lebih untuk melakukan pengungkapan mengenai kebijakan anti korupsi. Upaya ini dilakukan dalam rangka bentuk pertanggungjawab dan upaya pembuktian bahwa perusahaan terkait memiliki komitmen terhadap anti korupsi. Diharapkan dengan adanya pengungkapan ini dapat mencegah perilaku korupsi di perusahan dan memperoleh kembali kredibilitas dari publik.

Sehingga dapat dikatakan bahwa industri dengan risiko yang tinggi akan semakin terdorong melakukan upaya anti korupsi di perusahaan. Penelitian Healy dan Serafeim (2011) dalam jurnalnya menyatakan bahwa perusahaan yang beroperasi di lingkungan yang tinggi tingkat korupsinya, dapat melakukan pengungkapan yang luas dari upaya anti korupsi untuk mengkomunikasikan komitmen mereka kepada pemangku kepentingan internal dan eksternal, dan juga untuk mengurangi risiko. Hal ini selaras dengan penelitian Cooke (1992) dalam Tian dan Chen (2009). Dengan demikian, maka hipotesis dalam penelitian ini adalah :

\section{H5 : Semakin tingginya risiko industri, semakin tinggi pula kecenderungan perusahaan mengungkapkan kebijakan anti korupsi.}

\section{METODA PENELITIAN}

\section{Populasi dan Sampel}

Populasi dalam penelitian ini menggunakan perusahaan yang terdaftar di Bursa Efek Indonesia (BEI) pada tahun 2013 sampai 2017. Pemilihan sampel dilakukan dengan metoda pusposive sampling untuk mendapat sampel yang representative sesuai dengan kriteria yang ditentukan. Prosedur pemilihan sampel secara lengkap dapat dilihat pada tabel 1. Berdasarkan kriteria yang telah ditetapkan jumlah sampel akhir yang memiliki data lengkap sehingga dapat digunakan dalam penelitian ini adalah sebanyak 1619 perusahaan. 
Tabel 1.

Prosedur Pengambilan Sampel

\begin{tabular}{|c|l|c|c|c|c|c|c|}
\hline No & & $\mathbf{2 0 1 3}$ & $\mathbf{2 0 1 4}$ & $\mathbf{2 0 1 5}$ & $\mathbf{2 0 1 6}$ & $\mathbf{2 0 1 7}$ & Total \\
\hline 1. & $\begin{array}{l}\text { Perusahaan yang } \\
\text { terdaftar di BEI } \\
\text { periode 2013 } \\
\text { sampai 2017 }\end{array}$ & 431 & 457 & 476 & 492 & 518 & 2374 \\
\hline 2. & $\begin{array}{l}\text { Laporan Keuangan } \\
\text { yang tidak } \\
\text { menggunakan mata } \\
\text { uang Rupiah }\end{array}$ & $(73)$ & $(78)$ & $(78)$ & $(75)$ & $(77)$ & $(381)$ \\
\hline 3. & $\begin{array}{l}\text { Laporan tahunan } \\
\text { perusahaan yang } \\
\text { tidak dapat diakses }\end{array}$ & $(32)$ & $(33)$ & $(33)$ & $(32)$ & $(18)$ & $(148)$ \\
\hline $\begin{array}{l}\text { Laporan tahunan } \\
\text { yang tidak } \\
\text { menyajikan data } \\
\text { mengenai } \\
\text { Kompetensi } \\
\text { Komite Audit }\end{array}$ & $(45)$ & $(42)$ & $(49)$ & $(47)$ & $(43)$ & $(226)$ \\
\hline & $\begin{array}{l}\text { TOTAL SAMPEL } \\
\text { TOMI }\end{array}$ & $\mathbf{2 8 1}$ & $\mathbf{3 0 4}$ & $\mathbf{3 1 6}$ & $\mathbf{3 3 8}$ & $\mathbf{3 8 0}$ & $\mathbf{1 6 1 9}$ \\
\hline
\end{tabular}

\section{Jenis dan Sumber Data}

Jenis data yang digunakan dalam penelitian ini adalah data sekunder, dimana data dalam penelitian ini didapatkan dari media atau sumber informasi lain. Data dalam penelitian ini didapat dari website Bursa Efek Indonesia (BEI), serta website masing-masing perusahaan untuk memperoleh informasi mengenai laporan tahunan dan laporan keuangan perusahaan.

\section{Teknik Pengumpulan Data}

Penelitian ini menggunakan teknik pengumpulan data arsip. Teknik pengumpulan data arsip adalah teknik mengumpulkan data dari catatan atau basis data yang sudah ada (Jogiyanto, 2013).

\section{Pengukuran Variabel}

\section{a) Pengungkapan kebijakan anti korupsi}

Variabel dependen dalam penelitian ini adalah pengungkapan kebijakan anti korupsi. Berdasarkan Dissanayake (2011) dalam Joseph et al., (2016) pengungkapan kebijakan anti korupsi adalah sebuah mekanisme untuk mencegah perilaku atau tindakan yang tidak etis seperti korupsi, yang kaitannya dengan praktik CSR untuk organisasi laba. Variabel ini diukur menggunakan dummy, dimana perusahaan yang memiliki kecenderungan mengungkapkan kebijakan anti korupsi akan diberi skor satu (1) sedangkan perusahaan yang memiliki kecenderungan tidak mengungkapkan kebijakan anti korupsi akan diberi skor nol (0).

\section{b) Independensi Dewan Komisaris}

Komisaris independen adalah komisaris yang tidak berasal dari pihak terafiliasi atau pihak yang mempunyai hubungan bisnis dan kekeluargaan dengan pemegang saham pengendali, anggota direksi dan dewan komisaris lain, serta dengan perusahaan itu sendiri (Komite Nasional Kebijakan Governance, 2006). Variabel ini diukur dengan menggunakan perbandingan antara anggota dewan komisaris yang independen dengan keseluruhan anggota dewan komisaris. Variabel ini disimbolkan dengan KI. Perumusannya adalah sebagai berikut : 
Jumlah anggota komisaris independen

Jumlah seluruh anggota dewam komisaris

\section{c) Kompetensi Komite Audit}

Komite audit adalah sekelompok orang yang dipilih oleh kelompok yang lebih besar, untuk mengerjakan pekerjaan tertentu atau melakukan tugas-tugas khusus (Tugiman, 1995). Variabel ini diukur dengan menggunakan pembagian proporsi jumlah komite audit yang memiliki kompetensi di bidang akuntansi dan atau keuangan dengan keseluruhan jumlah komite audit di perusahan tersebut. Variabel ini disimbolkan dengan KA. Perumusannya adalah sebagai berikut :

$$
\frac{\text { Jumlah komite audit yang berkompeten }}{\text { Jumlah seluruh komite audit }}
$$

\section{d) Kepemilikan Institusional}

Menurut Gumilang dkk (2015) kepemilikan institusional merupakan suatu keadaan ketika saham mayoritas suatu perusahaan dimiliki oleh sebuah lembaga seperti, perusahaan asuransi, bank, perusahaan investasi, dan kepemilikan institusi lainnya.Variabel ini diukur dengan mencari perbandingan saham yang dimiliki institusi dengan jumlah saham yang beredar. Variabel ini disimbolkan INST. Perumusannya adalah sebagai berikut :

$\underline{\text { Jumlah saham yang dimiliki institusi }}$

Jumlah saham yang beredar

e) Ukuran Perusahaan

Menurut Ghozali (2013) dalam Yulio (2016), ukuran perusahaan adalah pengelompokan perusahaan ke dalam beberapa kategori yaitu perusahaan besar, perusahaan sedang dan perusahaan kecil yang didasarkan kepada total aset perusahaan. Variabel ini diukur dengan menggunakan logaritma natural dari total aset perusahaan. Variabel ini disimbolkan dengan LnASSET.

\section{f) Risiko Industri}

Risiko industri merupakan risiko yang dimiliki oleh suatu perusahaan yang diakibatkan oleh jenis industri yang dijalankan beserta dengan karakteristiknya, atau disebabkan oleh intensitas kegiatan industri tersebut. Risiko industri tersebut terbagi menjadi dua jenis, yaitu industri yang berisiko tinggi (high risk) dan industri yang berisiko rendah (low risk). Perusahaan yang termasuk klasifikasi industri high risk menurut Transparency International antara lain industri minyak dan gas, kehutanan, pertambangan, pertahanan, konstruksi, dan telekomunikasi. Variabel ini diukur dengan menggunakan variabel dummy dimana (1) berarti termasuk dalam industri high risk dan (0) berarti perusahaan termasuk dalam industri low risk. Variabel ini disimbolkan INDSTR.

\section{g) Keberagaman Gender dalam Anggota Komisaris}

Menurut Puspitawati (2013), gender adalah perbedaan peran, fungsi, status, dan tanggung jawab antara laki-laki dan perempuan yang terjadi karena adanya proses sosialisasi yang dialami secara terus menerus atau dari satu generasi ke generasi berikutnya. Artinya bahwa, yang akan dilihat dalam penelitian ini adalah mengenai peran perempuan dalam anggota komisaris dalam mendorong upaya pengungkapkan kebijakan anti korupsi. Variabel ini diukur dengan menggunakan perbandingan jumlah perempuan dari keseluruhan jumlah 
anggota komisaris. Variabel ini disimbolkan GENDER. Perumusannya adalah sebagai berikut :

$$
\frac{\text { Jumlah anggota komisaris perempuan }}{\text { Jumlah seluruh anggota komisaris }}
$$

\section{Analisis Regresi Logistik}

Regresi logistik digunakan karena data dependen dalam penelitian ini pengkategorian. Pengkategorian yang dimaksud adalah variabel pengungkapan kebijakan anti korupsi disajikan dalam dua kategori yaitu perusahaan yang memiliki kecenderungan untuk mengungkapkan kebijakan anti korupsi dan perusahaan yang memiliki kecenderungan tidak mengungkapkan kebijakan anti korupsi. Model regresi yang digunakan dalam penelitian ini adalah sebagai berikut :

$$
\begin{aligned}
& \text { Ln } \frac{p}{p-1}=\alpha_{0}+\beta_{1} \text { KI }+\beta_{2} \text { KA }+\beta_{3} \text { INST }+\beta_{4} \text { LNASSET }+\beta_{5} \\
& \text { INDSTR }+\beta_{6} \text { GENDER }+\mathrm{e}
\end{aligned}
$$

\begin{tabular}{|c|c|}
\hline $\operatorname{Ln} \frac{p}{p-1}$ & : Kecenderungan mengungkapan kebijakan anti korupsi \\
\hline & $\begin{array}{l}(1=\text { kecenderungan mengungkapkan kebijakan anti korupsi; } \\
0=\text { kecenderungan tidak mengungkapkan kebijakan anti korupsi) }\end{array}$ \\
\hline$\beta_{1-} \beta_{6}$ & : Koefisien variabel independen \\
\hline $\mathrm{KI}$ & : Independensi Dewan Komisaris \\
\hline KA & : Kompetensi Komite Audit \\
\hline INST & : Kepemilikan insitusional \\
\hline ASSET & : Logaritma natural aset \\
\hline INDSTR & : Risiko Industri \\
\hline GENDER & : Keberagaman Gender dalam anggota komisaris \\
\hline
\end{tabular}

Keterangan :

\section{Pengujian Hipotesis}

Pengujian hipotesis dilakukan menggunakan uji t. Uji t atau uji signifikan parameter individual menunjukkan seberapa besar pengaruh variabel independen secara individual terhadap variabel dependen (Murniati dkk, 2013). Karena penelitian ini menggunakan hipotesis satu arah dan positif $(+)$, maka kriteria penerimaan dan penolakan hipotesisnya adalah apabila nilai sig $/ 2<0,05$ dan $\beta$ positif (+) maka Ha diterima. Sebaliknya, apabila nilai sig/2 $\geq 0,05$ dan atau $\beta$ negatif (-) maka Ha ditolak.

\section{HASIL DAN PEMBAHASAN}

\section{Statistik Deskriptif}

Pada penelitian ini perusahaan akan dikelompokkan menjadi dua kategori, yakni perusahaan yang mengungkapkan kebijakan anti korupsi dan perusahaan yang tidak mengungkapkan kebijakan anti korupsi. Perusahaan sampel yang dapat diolah dalam penelitian ini adalah sebanyak 1619 perushaan. Perusahaan yang cenderung mengungkapkan kebijakan anti korupsi berjumlah 1434 perusahaan. Sedangkan perusahaan yang tidak mengungkapkan kebijakan anti korupsi adalah sebesar 185 perushaan. Berikut adalah tabel statistik deskriptif dan penjabarannya: 
Tabel 2.

Statistik Deskriptif

Panel A. Perusahaan Yang Mengungkapkan

\begin{tabular}{|l|r|r|r|r|r|}
\hline & \multicolumn{1}{|c|}{$\mathrm{N}$} & Minimum & Maximum & \multicolumn{1}{|c|}{ Mean } & Std. Deviation \\
\hline Independensi Dewan & 1434 & .17 & 1.00 & .4333 & .12364 \\
Komisaris & 1434 & .25 & 1.00 & .8549 & .20345 \\
Kompetensi Komite Audit & 1434 & .00 & 1.00 & .6754 & .21552 \\
Kepemilikan Institusional & 1434 & 7.95 & 20.84 & 15.1018 & 1.90317 \\
Ukuran Perusahaan & 1434 & .00 & 1.00 & .1318 & .33839 \\
Risiko Industri & 1434 & .00 & 1.00 & .1226 & .18047 \\
Keberagaman Gender & 1434 & & & & \\
Valid N (listwise) & & & \\
\hline
\end{tabular}

Panel B: Perusahaan Yang Tidak Mengungkapkan

\begin{tabular}{|l|r|r|r|r|r|}
\hline & \multicolumn{1}{|c|}{$\mathrm{N}$} & Minimum & Maximum & \multicolumn{1}{c|}{ Mean } & Std. Deviation \\
\hline Independensi Dewan & 185 & .25 & .75 & .4025 & .10207 \\
Komisaris & 185 & .33 & 1.00 & .8391 & .21185 \\
Kompetensi Komite Audit & 185 & .00 & .99 & .6636 & .24676 \\
Kepemilikan Institusional & 185 & 10.11 & 19.26 & 13.6719 & 1.54014 \\
Ukuran Perusahaan & 185 & .00 & 1.00 & .1568 & .36456 \\
Risiko Industri & 185 & .00 & 1.00 & .1207 & .21743 \\
Keberagaman Gender & 185 & & & & \\
Valid N (listwise) & & & & \\
\hline
\end{tabular}

Dari panel A dan panel B tabel 2 dapat dilihat bahwa perusahaan-perusahaan yang mengungkapkan kebijakan anti korupsi memiliki rata-rata independensi dewan komisaris sebesar 0,4333. Hal ini mengindikasikan bahwa perusahaan yang mengungkapkan kebijakan anti korupsi rata-rata mempunyai jumlah komisaris independen sebesar 43,33\% dari total keseluruhan dewan komisaris. Di sisi lain, perusahaan yang tidak mengungkapkan kebijakan anti korupsi memiliki rata-rata independensi dewan komisaris sebesar 0,4025. Artinya bahwa perusahaan yang tidak mengungkapkan kebijakan anti korupsi rata-rata mempunyai jumlah komisaris independen sebesar 40,25\% dari total keseluruhan dewan komisaris.

Perusahaan-perusahaan yang mengungkapkan kebijakan anti korupsi memiliki rata-rata kompetensi komite audit sebesar 0,8549 . Hal ini mengindikasikan bahwa perusahaan yang mengungkapkan kebijakan anti korupsi rata-rata mempunyai jumlah komite audit yang berkompeten di bidang akuntansi dan atau keuangan sebesar $85,49 \%$ dari total keseluruhan komite audit. Di sisi lain perusahaan yang tidak mengungkapkan kebijakan anti korupsi memiliki rata-rata kompetensi komite audit sebesar 0,8391. Artinya bahwa perusahaan yang tidak mengungkapkan kebijakan anti korupsi rata-rata mempunyai jumlah komite audit yang kompeten di bidang akuntansi atau keuangan sebesar 83,91\%.

Perusahaan-perusahaan yang mengungkapkan kebijakan anti korupsi memiliki rata-rata kepemilikan institusional sebesar 0,6754. Hal ini mengindikasikan bahwa pihak institusional pada perusahaan yang mengungkapkan kebijakan anti korupsi rata-rata memiliki saham perusahaan sebesar 67,54\%. Di sisi lain, perusahaan yang tidak mengungkapkan kebijakan anti korupsi memiliki rata-rata kepemilikan institusional sebesar 0,6636. Artinya bahwa pihak institusional pada perusahaan yang tidak mengungkapkan kebijakan anti korupsi rata-rata memiliki saham perusahaan sebesar $66,36 \%$.

Perusahaan-perusahaan yang mengungkapkan kebijakan anti korupsi memiliki rata-rata nilai logaritma natural aset sebesar 15,1018. Hal ini mengindikasikan bahwa perusahaan yang 
mengungkapkan kebijakan anti korupsi rata-rata adalah perusahaan yang besar atau menengah ke atas karena memiliki logaritma natural aset yang cukup tinggi. Di sisi lain perusahaan yang tidak mengungkapkan kebijakan anti korupsi memiliki rata-rata nilai logaritma natural aset sebesar 13,6719. Artinya bahwa perusahaan yang tidak mengungkapkan kebijakan anti korupsi rata-rata adalah perusahaan yang kecil karena memiliki logaritma natural aset yang rendah.

Tabel 3.

Risiko Industri

\begin{tabular}{|ll|r|r|r|r|}
\hline & & Frequency & Percent & Valid Percent & $\begin{array}{c}\text { Cumulative } \\
\text { Percent }\end{array}$ \\
\hline Valid & Low risk & 1401 & 86.5 & 86.5 & 86.5 \\
& High Risk & 218 & 13.5 & 13.5 & 100.0 \\
& Total & 1619 & 100.0 & 100.0 & \\
\hline
\end{tabular}

Tabel 4 menyajikan statistik deskriptif risiko industri. Perusahaan dibagi menjadi dua kelompok, yakni perusahaan high risk dan low risk. Perusahaan yang tergolong high risk dalam penelitian ini berjumlah 1401 perusahaan atau sebesar 86,53\%. Sedangkan perusahan low risk dalam penelitian ini berjumlah 218 perusahaan atau sebesar 13,46\%. Hal tersebut menunjukkan bahwa perusahaan yang tergolong dalam industri low risk yang menjadi sampel dalam penelitian lebih besar dibandingkan perusahaan yang tergolong industri high risk.

Perusahaan-perusahaan yang mengungkapkan kebijakan anti korupsi memiliki rata-rata risiko industri sebesar 0,1318 . Sedangkan perusahaan yang tidak mengungkapkan kebijakan anti korupsi memiliki nilai rata-rata risiko industri sebesar 0,1568. Hal tersebut mengindikasikan perusahaan yang mengungkapkan kebijakan anti korupsi memiliki risiko industri yang lebih rendah bila dibandingkan dengan perusahaan yang tidak mengungkapkan.

\section{Analisis Regresi Logistik Kelayakan Model}

Tabel 4 menyajikan hasil uji kelayakan model dengan omnibus test. Dari tabel 4 dapat diketahui bahwa nilai signifikansi uji chi-square goodness of fit sebesar 0,000 atau kurang dari 0,05. Hal ini menunjukkan bahwa model regresi logistik sudah tepat dan dapat digunakan untuk proses pengujian selanjutnya.

Tabel 4.

Kelayakan Model Regresi Logistik

Omnibus Tests of Model Coefficients

\begin{tabular}{|rl|r|r|r|}
\hline & & Chi-square & df & \multicolumn{1}{c|}{ Sig. } \\
\hline Step 1 & Step & 109.026 & 6 & .000 \\
& Block & 109.026 & 6 & .000 \\
& Model & 109.026 & 6 & .000 \\
\hline
\end{tabular}

\section{Uji Koefisien Determinasi}

Berdasarkan tabel 5 dapat diketahui bahwa nilai koefisen determinasi adalah sebesar 0,128 atau sebesar 12,8\%. Sehingga diperoleh kesimpulan bahwa kemampuan variabel independen dalam menjelasakan variasi dalam pengungkapkan kebijakan anti korupsi di perusahaan adalah sebesar $12,8 \%$. Sedangkan sisanya yakni sebesar $87,2 \%$ dijelaskan oleh faktor lain diluar penelitian. 
Tabel 5.

Koefisien Determinasi

Model Summary

\begin{tabular}{|l|c|c|c|}
\hline Step & $\begin{array}{c}-2 \text { Log } \\
\text { likelihood }\end{array}$ & $\begin{array}{c}\text { Cox \& Snell R } \\
\text { Square }\end{array}$ & $\begin{array}{c}\text { Nagelkerke R } \\
\text { Square }\end{array}$ \\
\hline 1 & $1041.587^{\mathrm{a}}$ & .065 & .128 \\
\hline
\end{tabular}

a. Estimation terminated at iteration number 6 because parameter estimates changed by less than .001 .

\section{Uji Kelayakan Keseluruhan Model Regresi Logistik}

Tabel menyajikan hasil uji kelayakan model menggunakan Hosmer dan Lemeshow test. Nilai signifikansi Hosmer and Lemeshow Test sebesar 0,192 atau lebih dari 0,05 menunjukkan bahwa model regresi logistik yang dibuat telah mampu menjelaskan data dalam penelitian sehingga data dapat digunakan untuk analisis selanjutnya.

Tabel 6.

Uji Kelayakan Keseluruhan Model Regresi

Hosmer and Lemeshow Test

\begin{tabular}{|l|r|r|r|}
\hline Step & Chi-square & \multicolumn{1}{c|}{ df } & Sig. \\
\hline 1 & 11.178 & 8 & .192 \\
\hline
\end{tabular}

\section{Uji Kemampuan Pengklasifikasian}

Berdasarkan tabel 7 menunjukkan bahwa kemampuan model regresi logistik untuk mengklasifikasikan data dengan benar adalah sebesar $88,1 \%$. Sehingga dapat dikatakan bahwa model regresi yang dibuat telah cukup baik dalam mengklasifikasikan data sehingga dapat digunakan untuk pengujian hipotesis.

Tabel 7.

\section{Uji Kemampuan Pengklasifikasian}

\begin{tabular}{|c|c|c|c|c|c|}
\hline \multicolumn{6}{|c|}{ Classification Table $^{a}$} \\
\hline & & & \multicolumn{3}{|c|}{ Predicted } \\
\hline & & & \multicolumn{2}{|c|}{ Pengungkapan Anti Korupsi } & \multirow[b]{2}{*}{$\begin{array}{c}\text { Percentage } \\
\text { Correct }\end{array}$} \\
\hline & Observed & & $\begin{array}{c}\text { Tidak } \\
\text { Mengungkapk } \\
\text { an Anti } \\
\text { Korupsi }\end{array}$ & $\begin{array}{c}\text { Mengungkapk } \\
\text { an Anti } \\
\text { Korupsi }\end{array}$ & \\
\hline \multirow[t]{3}{*}{ Step 1} & $\begin{array}{l}\text { Pengungkapan Anti } \\
\text { Korupsi }\end{array}$ & $\begin{array}{l}\text { Tidak Mengungkapkan } \\
\text { Anti Korupsi }\end{array}$ & 0 & 185 & .0 \\
\hline & & $\begin{array}{l}\text { Mengungkapkan Anti } \\
\text { Korupsi }\end{array}$ & 7 & 1427 & 99.5 \\
\hline & Overall Percentage & & & & 88.1 \\
\hline
\end{tabular}

a. The cut value is .500

\section{HASIL DAN PEMBAHASAN}

\section{Independensi Dewan Komisaris dan Kebijakan Anti Korupsi}

Tabel 8 menampilkan hasil pengujian menggunakan regresi logistik. Dari hasil pengujian hipotesis menunjukkan bahwa terdapat korelasi positif antara independensi dewan 
komisaris dan kecenderungan pengungkapan kebijakan anti korupsi. Hal ini terdukung secara statistik dengan nilai sig/2 sebesar 0,02 atau kurang dari 0,05 dan beta positif sebesar 1,599 yang artinya bahwa hipotesis diterima.

Tabel 8.

Hasil Analisis Regresi Logistik

Variables in the Equation

\begin{tabular}{|ll|r|r|r|r|r|r|}
\hline & & \multicolumn{1}{c|}{ B } & \multicolumn{1}{c|}{ S.E. } & \multicolumn{1}{c|}{ Wald } & \multicolumn{1}{c|}{ df } & \multicolumn{1}{c|}{ Sig. } & \multicolumn{1}{c|}{ Exp(B) } \\
\hline Step 1 ${ }^{\mathrm{a}}$ & KI & 1.599 & .779 & 4.208 & 1 & .040 & 4.948 \\
& KA & .449 & .384 & 1.364 & 1 & .243 & 1.567 \\
& .250 & .358 & .490 & 1 & .484 & 1.284 \\
INST & .450 & .049 & 84.893 & 1 & .000 & 1.568 \\
LNASSET & -.450 & .233 & 3.732 & 1 & .053 & .638 \\
INDSTR & .508 & .421 & 1.453 & 1 & .228 & 1.662 \\
GENDER & -5.618 & .863 & 42.354 & 1 & .000 & .004 \\
\hline
\end{tabular}

a. Variable(s) entered on step 1: KI, KA, INST, LNASSET, INDSTR, GENDER.

Dengan semakin independennya dewan komisaris maka semakin ketat pengawasan yang terjadi di perusahaan. Selain itu, dewan komisaris juga punya kewajiban untuk menjaga kepentingan para pemegang saham dan pemangku kepentingan lain di dalam perusahaan. Sehingga dewan komisaris yang independen melakukan upaya untuk menjaga kelangsungan hidup perusahaan, salah satunya adalah mendorong kecenderungan pengungkapan informasi mengenai kebijakan anti korupsi. Kebijakan anti korupsi dianggap cukup untuk menggambarkan bahwa perusahaan tersebut memiliki komitmen terhadap pemberantasan korupsi. Sehingga pengungkapan kebijakan ini dirasa perlu dilakukan untuk mencegah korupsi dan meningkatkan kredibilitas perusahaan. Penelitian ini mendukung penelitian yang dilakukan oleh Healy Serafeim (2015) yang dikutip dalam de Melo (2015) serta Healy Serafeim (2014) dalam Joseph et al., (2016).

\section{Kompetensi Komite Audit dan Kebijakan Anti Korupsi}

Dari tabel 8 juga dapat diketahui hubungan antara kompetensi komite audit dengan kecenderungan pengungkapan kebijakan anti korupsi tidak terdukung secara statistik dengan nilai sig/2 sebesar 0,1215 atau lebih dari 0,05 dan beta positif sebesar 0,449. Dengan deimikian hipotesis dua ditolak. Penolakan hipotesis ini kemungkinan karena ada kompetensi dibidang lain yang dirasa lebih efektif dan relevan untuk mendorong pengungkapan kebijakan anti korupsi di perusahaan. Misalnya saja latar belakang pendidikan di bidang hukum yang dianggap lebih memahami peraturan hukum mengenai korupsi.

Dugaan lain penolakan hipotesis ini adalah karena istilah korupsi merupakan sesuatu hal yang umum, maka tidak diperlukan kompetensi khusus untuk mendorong kesadaran dalam melakukan pengungkapan anti korupsi di perusahaan tersebut. Selain itu, pada dasarnya tugas komite audit secara umum di perusahaan menurut Komite Nasional Kebijakan Governance (KNKG) adalah sebagai berikut (1) memastikan bahwa laporan keuangan disajikan secara wajar sesuai dengan prinsip akuntansi yang berlaku umum, (2) memastikan struktur pengendalian internal perusahaan dilaksanakan dengan baik, (3) memastikan pelaksanaan audit internal maupun eksternal dilaksanakan sesuai standar audit yang berlaku, dan (4) memastikan tindak lanjut temuan hasil audit dilaksanakan oleh manajemen. Sehingga dengan demikian kemungkinan seorang komite audit perlu memiliki sertifikasi khusus agar mampu mendorong pengungkapan anti korupsi di perusahaan. Penelitian ini bertolak belakang dengan penelitian 
yang dilakukan oleh Bedard dan Gendron (2010) dalam Musallam (2018) serta penelitian dari Allegrini dan Greco (2013).

\section{Kepemilikan Institusional dan Pengungkapan Kebijakan Anti Korupsi}

Masih dari tabel 8 dapat dilihat bahwa hubungan antara kepemilikan institusional dengan kecenderungan pengungkapan kebijakan anti korupsi tidak terdukung secara statistik dengan nilai sig/2 sebesar 0,242. Dengan demikian hipotesis tiga ditolak. Hal ini kemungkinan disebabkan karena struktur kepemilikan saham di Indonesia cenderung terkonsentrasi. Pemilik saham terkonsentrasi sebagai investor bisa saja memiliki kecenderungan beritikad buruk, artinya bahwa niat investasinya hanya untuk eksploitasi atau hanya berdasar pada kepentingan sendiri saja. Sehingga pemilik saham terkonsentrasi mempedulikan pengungkapan informasi yang dilakukan perusahaan.

Selain itu apabila dilihat dari perspektif investasi, kemungkinan investor institusional memiliki perspektif jangka pendek. Akibatnya investor tersebut hanya peduli terhadap kenaikan harga saham jangka pendek, tanpa mempedulikan bagaimana pemantauan atau tata kelola yang ada di perusahaan.Sehingga dengan dapat disimpulkan bahwa kemungkinan investor tersebut hanya berfokus pada kepentingan investasinya. Sedangkan mengenai pengungkapan informasi yang lebih luas, misalnya mengenai pengungkapan kebijakan anti korupsi sepenuhnya merupakan keputusan dan pilihan dari pihak manajemen. Sehingga dengan demikian dapat dikatakan bahwa kepemilikan saham oleh pihak institusional tidak mempengaruhi pengungkapan kebijakan anti korupsi yang dilakukan oleh perusahaan. Penelitian bertolak belakang dengan penelitian yang dilakukan oleh Rouf dan Harun (2011) serta El-Gazzar (1998) dalam Eng dan Mak (2003).

\section{Ukuran Perusahaan dan Kebijakan Anti Korupsi}

Hasil pengujian hipotesis yang ditampilkan dalam tabel 8 menunjukkan bahwa terdapat korelasi positif antara ukuran perusahaan dengan kecenderungan pengungkapan kebijakan anti korupsi. Hal ini terdukung secara statistik dengan nilai sig/2 sebesar 0,000 atau signifikan pada tingkat kurang dari 1\%. Dengan demikian hipotesis empat diterima. Hasil penelitian ini menunjukkan bahwa semakin besar ukuran perusahaan akan mendorong kecenderungan pengungkapan kebijakan anti korupsi di perusahaan.

Perusahaan besar merasa memiliki tanggung jawab yang lebih karena menjadi sorotan publik dan memiliki koneksi dengan banyak pihak. Sehingga sebagai wujud pertanggungjawaban dan mempertahankan kredibilitasnya perusahaan besar merasa perlu mengungkapkan kebijakan mengenai anti korupsi. Dengan adanya kebijakan ini mencerminkan bahwa perusahaan mempunyai mekanisme pencegahan agar tidak terlibat kasus korupsi. Karena apabila perusahaan besar terjerat korupsi maka kerugian finansial maupun non finansial harus siap ditanggung oleh perusahaan. Penelitian ini mendukung penelitian yang dilakukanHealy dan Serafeim (2011) sertaPatten (1991).

\section{Risiko Industri dan Kebijakan Anti Korupsi}

Hasil pengujian hipotesis yang disajikan dalam tabel 8 menunjukkan bahwa terdapat korelasi negatif antara risiko industri dengan kecenderungan pengungkapan kebijakan anti korupsi dengan nilai sig/2 sebesar 0,0265 dan koefisien beta -0,450. Karena arahnya tidak sesuai dengan prediksi maka hipotesis lima ditolak. Hasil penelitian ini menunjukkan bahwa perusahaan yang berada pada risiko yang tinggi terhadap korupsi maka memiliki kecenderungan untuk tidak mengungkapkan kebijakan anti korupsi.

Perusahaan yang beroperasi di lingkungan dengan tingkat risiko korupsi yang tinggi mendapat tekanan atau stigma negatif dari masyarakat. Selain itu perusahaan yang tergolong 
high risk lebih berpotensi memiliki banyak konflik dan permasalahan di dalam perusahaannya. Menyikapi keadaan ini, pihak manajer lebih memilih untuk menutup diri atau tidak mengungkapkan kebijakan anti korupsi dalam rangka berusaha menutup-nutupi perilaku buruk atau permasalahan yang ada di perusahaannya. Oleh karena itu, perusahaan yang beroperasi di lingkungan industri yang tinggi risiko korupsinya akan lebih rendah pengungkapan kebijakan anti korupsinya. Hasil penelitian ini bertolak belakang dengan penelitian Healy dan Serafeim (2011)yang menyatakan bahwa perusahaan yang beroperasi di lingkungan yang tinggi tingkat korupsinya, dapat melakukan pengungkapan yang luas dari upaya anti korupsi untuk mengkomunikasikan komitmen mereka kepada pemangku kepentingan internal dan eksternal, dan juga untuk mengurangi risiko.

\section{Variabel Kontrol}

Variabel keberagaman gender dalam anggota komisaris memiliki nilai sig/2 sebesar 0,114 atau lebih dari 0,05 dan beta positif sebesar 0,508. Hal ini menandakan bahwa keberagaman genderdalam anggota komisaris tidak berpengaruh terhadap kecenderungan pengungkapan anti korupsi di perusahaan. Hasil pengujian ini konsisten dengan penelitian Feijoo et al (2012) yang dikutip dalam de Melo(2015) serta Swamyet al(2000).

\section{SIMPULAN DAB SARAN}

\section{Kesimpulan}

Penelitian ini bertujuan untuk menguji pengaruh elemen Good Corporate Governance (independensi dewan komisaris, kompetensi komite audit, dan kepemilikan institusional) serta karakteristik perusahaan (ukuran perusahaan dan risiko industri) terhadap kecenderungan mengungkapkan kebijakan anti korupsi di perusahaan Indonesia yang terdaftar di Bursa Efek Indonesia (BEI) pada tahun 2013-2017. Berdasarkan hasil analisis dan pembahasan, maka kesimpulan yang dapat diambil dari penelitian ini adalah sebagai berikut :

1. Independensi dewan komisaris (KI) berpengaruh positif terhadap kecenderungan mengungkapkan kebijakan anti korupsi. Hasil penelitian ini selaras dengan penelitian yang dilakukan oleh Healy Serafeim (2015) yang dikutip dalam de Melo(2015) serta Healy Serafeim (2014) yang dikutip dalam Joseph et al., (2016).

2. Kompetensi komite audit di bidang akuntansi dan atau keuangan (KA) tidak berpengaruh terhadap kecenderunga mengungkapkan kebijakan anti korupsi. Hasil penelitian ini tidak selaras dengan penelitian yang dilakukan oleh Bedard dan Gendron (2010) dalam(Musallam, 2018) serta Allegrini dan Greco (2013).

3. Kepemilikan saham oleh institusi atau yang biasa disebut dengan kepemilikan institusional (INST) tidak berpengaruh terhadap kecenderungan mengungkapkan kebijakan anti korupsi. Hasil penelitian ini tidak selaras dengan penelitian yang dilakukan oleh Rouf dan Harun(2011) serta El-Gazzar (1998) dalam Eng dan Mak(2003).

4. Ukuran perusahaan (LNASSET) berpengaruh positif terhadap kecenderungan mengungkapan kebijakan anti korupsi. Hasil penelitian ini selaras dengan penelitian yang dilakukan oleh Healy dan Serafeim(2011) serta Patten(1991).

5. Risiko industri (INDSTR) berpengaruh negatif terhadap pengungkapan kebijakan anti korupsi yang dilakukan perusahaan. Hasil penelitian ini tidak selaras dengan penelitian Healy dan Serafeim (2011).

6. Variabel kontrol keberagaman gender dalam anggota komisaris (GENDER) berpengaruh positif terhadap pengungkapan kebijakan anti korupsi yang dilakukan perusahaan. Hasil penelitian ini selaras dengan penelitian yang dilakukan oleh Feijoo et al (2012) yang dikutip dalam de Melo(2015) serta (Swamyet al, 2000). 


\section{Saran}

Adapun saran yang dapat penulis berikan adalah sebagai berikut:

1. Bagi perusahaan. Secara keseluruhan hasil penelitian ini menggambarkan bahwa masih terdapat banyak perusahaan yang memiliki kecenderungan tidak mengungkapkan kebijakan anti korupsi di perusahannya. Fenomena ini menandakan bahwa masih rendahnya kesadaran perusahaan di Indonesia akan manfaat mengungkapkan kebijakan anti korupsi dan rendahnya pula kemauan untuk memaparkan informasi tersebut dalam laporan tahunan perusahaan. Maka dari itu alangkah lebih baik apabila perusahaan yang terdaftar di Bursa Efek Indonesia lebih meningkatkan kesadaran akan pentingnya membuat komitmen mengenai tindakan anti korupsi dan mengungkapkan komitmen anti korupsi tersebut dalam laporan tahunan.

2. Bagi penelitian selanjutnya. Apabila peneliti selanjutnya akan mengangkat kembali topik serupa diharapkan dapat menambah variabel pembeda diantaranya variabel frekuensi rapat dewan direksi, serta frekuensi rapat komite audit. Diharapkan dengan adanya variabel pembeda tersebut dapat menambah variasi variabel dan semakin menambah wawasan pembaca mengenai variabel apa saja yang dapat mempengaruhi pengungkapan kebijakan anti korupsi di perusahaan.

\section{DAFTAR PUSTAKA}

Allegrini, M. and G. Greco. 2013. Corporate Boards, Audit Committees And Voluntary Disclosure: Evidence From Italian Listed Companies. Journal of Management and Governance, 17(1): 187-216.

Anti-Corruption Clearing House. 2018. Tindak Pidana Korupsi Berdasarkan Profesi atau Jabatan. Diakses pada tanggal 5 November 2018, pukul 16.30 WIB dari https://acch.kpk.go.id/id/statistik/tindak-pidana-korupsi/tpk-berdasarkan-profesi-jabatan

Berthelot, S. and A. M. Robert. 2011. Climate change disclosures: An examination of Canadian oil and gas firms. Journal of Social and Environmental Accounting,5(1): 106123.

De Melo, R. B. E. 2015. Essays On Anti-Corruption Disclosure. ProQuest Dissertations and Theses, 25(2): 1-103

Eng, L. L. and Y.T. Mak. 2003. Corporate governance and voluntary disclosure. Journal of Accounting and Public Policy, 22(4): 325-345.

Gumilang, F., Suhadak dan S. Mangesti. 2015. Pengaruh Kepemilikan Institusional dan Asimetri Informasi Terhadap Manajemen Laba (Studi Pada Perusahaan Manufaktur Yang Terdaftar Di Bursa Efek Indonesia Tahun 2011 -2013). Jurnal Administrasi Bisnis, 23(1): $1-8$.

Healy, P., and G. Serafeim. 2011. Causes and Consequences of Firms'Self-Reported Anticorruption Efforts. SSRN Electronics Journal, 5: 1-43

Jensen, C. and H. Meckling. 1976. Theory Of The Firm : Managerial Behavior, Agency Costs And Ownership Structure. Journal of Financial Economics, 3: 305-360. 
Joseph, C., J. Gunawan, Y. Sawani, M. Rahmat, J. A. Noyem, and F. Darus. 2016. A comparative study of anti-corruption practice disclosure among Malaysian and Indonesian Corporate Social Responsibility (CSR) best practice companies. Journal of Cleaner Production, 112: 2896-2906.

Karim, N. K. dan E. E. Sasanti. 2016. Pengungkapan Anti Korupsi dan Kinerja Keuangan Perusahaan: Studi Kasus Perusahaan Terdaftar Di Indeks Sri Kehati. Jurnal Riset Akuntansi Aksioma, 15(2): 28-52.

Komite Nasional Kebijakan Governance. 2006. Pedoman Umum Good Corporate Governance Indonesia. Diakses pada tanggal 8 Juli 2018, dari http://www.gmf-aeroasia.co.id/wpcontent/uploads/bsk-pdf-manager/42_PEDOMAN_GCG_INDONESIA_2006.PDF

Marzuki. 2007. Kajian Awal Tentang Teori-Teori Gender. Diakses pada tanggal 15 Agustus 2018, dari https://journal.uny.ac.id/index.php/civics/article/downloadSuppFile/6032/927

Murwaningsari, E. 2009. Hubungan Corporate Governance, Corporate Social Responsibilities dan Corporate Financial Performance dalam Satu Continuum. Jurnal Akuntansi Dan Keuangan, 11(1): 30-41.

Murniati, M. P., S. V. Purnamasari, S. D. Ayu, A. Advensia, R. Sihombing, dan Y. Warastuti. 2013. Alat-Alat Pengujian Hipotesis. Semarang : Universitas Katolik Soegijapranata.

Musallam, S. R. M. 2018. The Direct and Indirect effect of the existence of risk managemen on the relationship between audit committee and corporate social responsibility disclosure. Benchmarking : An International Journal, 315: 1-16.

Peraturan Otoritas Jasa Keuangan No. 33 tahun 2014 tentang Direksi dan Dewan Komisaris Emiten atau Perusahaan Publik. Diunduh pada tanggal 15 November 2018, dari http://eodb.ekon.go.id/download/peraturan/lainlain/ojk/POJK_33_2014.pdf

Patten, D. M. 1991. Exposure, legitimacy, and social disclosure. Journal of Accounting and Public Policy, 10(4): 297-308.

Puspitawati, H. 2013. Konsep, Teori dan Analisis Gender. JurnalKomunikasi Pembangunan, 4: $1-16$.

Putra, A. A. 2016. Pengaruh Good Corporate Governance Terhadap Nilai Perusahaan. Jurnal Ekonomi KIAT, 27(2): 1-16.

Rouf, M. A. and M. A. Al-Harun. 2011. Ownership Structure and Voluntary Disclosure in Annual Reports of Bangladesh. Review of Economic and Business Studies, 5(1):129-139.

Sullivan, J. D., A. Wilson, and A. Nadgrodkiewicz. 2013. The Role of corporate governance in fighting corruption. Journal of Accounting and Public Policy, 44(1): 1-21.

Swamy, A., S. Knack., Y. Lee., and O. Azfar. 2000. Gender and Corruption. Journal of Development Economics, 121(40): 1-39.

Tian, Y. and J. Chen. 2009. Concept of Voluntary Information Disclosure and A Review of 
Relevant Studies. International Journal of Economics and Finance, 1(2): 55-59.

Transparency International. 2018. Corruption Perception Index 2017.Diakses tanggal 8 Juli 2018,darihttps://www.transparency.org/news/feature/corruption_perceptions_index2017.

Trotman, K. T. and G. W. Bradley. 1981. Associations between social responsibility disclosure and characteristics of companies. Journal ofAccounting, Organizations and Society, 6(4): 355-362.

Undang-Undang Republik Indonesia No. 20 tahun 2008 tentang Usaha Mikro, Kecil, dan Menengah. Diunduh pada tanggal 15 November 2018, dari www.bi.go.id.

Widyatama, A. 2014. Good Corporate Governance Dan Corporate Social Responsibility: Sebuah Tinjauan Empiris. Jurnal Akuntansi Aktual, 2: 312-321.

Yulio, W. S. 2016. Pengaruh Konvergensi IFRS, Komite Audit dan Kompleksitas Perusahaan Terhadap Fee Audit. Jurnal Akuntansi Bisnis, XV(29): 77-92. 